\section{ACCESSIBILITY TO NODES OF INTEREST: DISLOCATION OF THE INDUSTRIAL DISTRICTS OF TUSCANY}

\author{
Gioacchino de Candia \\ Studio de Candia, \\ via Salgari, 6, Terlizzi, Italy
}

\begin{abstract}
:
The present research starts by a series of experiences gained by the author on the theme of attractiveness/accessibility of territories, in light of the most recent dynamics for the analysis. The equation model used is of gravitational type. Specifically, the impedance function is used in the form of logistics, which has so far provided the best results in the analysis of territories. The research is conducted at the municipal level. The paper aims to analyze the connection between these works and the map of industrial districts, recently produced by ISTAT. The analyzed region, as in other publications, is Tuscany, which provides the details on the municipal map of accessibility in relation to the location of industrial clusters. The metropolitan city of Florence is treated separately. The aim is to provide policy makers with the best socio-economic information for the economic and financial administration of territories.
\end{abstract}

\section{Key words:}

regional development, impedance curves, territorial statistics, infrastructure, industrial districts, municipality.

\section{INTRODUCTION}

Industrial districts are a typical production model of the Italian economy. Starting from the notion of industrial districts theory, which has its roots in the works of Marshall (1890), further studies have found fertile ground in Italy. Following the theoretical and empirical contribution of Giacomo Becattini (1979), further analysis on industrial districts has been conducted, producing a substantial empirical study on the subject. The National Institute of Statistics (ISTAT) has developed a list of industrial clusters identified from local labor systems, the latter identified to commuting between municipalities for work, collected during the $15^{\text {th }}$ General Census of Population, which altered the map of the local labor systems (ISTAT, 2014).

The criteria for identifying districts used by ISTAT refer to the classic concept of industrial district, the source of Marshall and Becattini in Italy (Marshall, 1890; Becattini, 2000) and are to identify the local systems characterized by the presence of small or medium-sized enterprises, 
with a high spatial concentration of manufacturing employment focused in the major industry, while other companies present in the local system are complementary or auxiliary.

The ISTAT procedure in 2011 led to identification of 141 industrial districts from 611 local systems on the Italian territory.

In this report, we analyze the distribution of districts in the region of Tuscany, in the light of the map of the territorial attractiveness/ accessibility analyzed in the previous work of the author.

\section{MATERIALS AND METHODS}

The starting point are the publications produced by the author on the issue of accessibility to nodes of interest (de Candia et al., 2014; de Candia, 2015) and the map of industrial districts recently developed by ISTAT (2015).

The map of industrial districts is overlaid with figures relative to the "summary of impedance function in the form of logistics, by arithmetic average" and pie charts relating to the synthesis, the impedance functions in the form of logistics, weighted by the resident population. The reference territory are the municipalities in Tuscany.

As regards the processing of accessibility/attractiveness, reference is made to the model defined "gravitational", according to the known equation:

$$
A_{i}=\sum_{j \in D} W_{j}^{\beta} f\left(c_{i, j}, \alpha\right)
$$

where $A_{i}$ is the accessibility of a resident of the area $i$ compared to the nodes $j$ in the region $D$, $W_{j}^{\beta}$ is a measure of activities or services (mass opportunities) in the area $j, \beta$ is a calibration parameter (used to account for the effects of agglomeration) and $f\left(c_{i, j}\right)$ is a function of impedance generally decreasing with the cost $c_{i, j}$ (or the distance or travel time).

The impedance $f\left(c_{i, j}, \alpha\right)$ function takes the form of logistics, already used successfully by the author:

$$
f\left(c_{i, j}\right)=\left(\frac{1}{1+\exp -k\left(c_{i, j}-c_{0}\right)}\right)
$$

with

$c_{0}=\frac{1}{2}\left(c_{\min }+c_{\text {max }}\right)$

where $c_{\text {min }}$ is the minimum cost and $c_{\text {max }}$ the maximum observed cost and

$$
k=2 \ln \left(\frac{1}{\gamma}-1\right) /\left(c_{\text {max }}-c_{\text {min }}\right) \quad \gamma>0
$$

The impedance functions are synthesized using the simple average between indices. An additional summary of results shows the weighted arithmetic mean, using the resident population as calculated based on the $15^{\text {th }}$ Italian Population and Housing Census (ISTAT, 2011). According to the experience gained by the author, two different approaches emerge, namely the one called "weighted average" (WA), and the other one "average weighted index" (AWI), with the following formulations:

$$
\begin{aligned}
& \mu_{i}=\sum_{i j}\left(x_{i j} / p_{i}\right) * 100 \quad \text { (weighted average - WA) } \\
& \mu=\sum_{i j} \mu_{i} / n \quad \text { (average weighted index - AWI) } \\
& \mu_{i}=\sum_{i j}\left(x_{i j} p_{i}\right) / p_{i} \quad \\
& \mu=\sum_{i j} \mu_{i} / n \quad
\end{aligned}
$$

where $x_{i j}$ is the impedance function developed for the municipalities $i$ and infrastructure $j$, and $p_{i}$ is the population of the municipality $j$, while $\mu_{i}$ is the weighted arithmetic mean for each municipality $i$.

The infrastructure considered at the municipal level is as follows:

- hospitals (public and private);

- grade schools (upper secondary level);

- railway stations (platinum, gold and silver);

- airports.

As for the methodology for development of industrial clusters by ISTAT, the procedure was adopted for 2011 using the criteria introduced for identification of industrial districts in 2001 based on the use of the territorial concentration coefficient. 
The procedure is hierarchical and comprises four steps aimed at:

1. identification of local systems, mainly manufacturing;

2. identification of local systems, mainly manufacturing of small to medium-sized enterprises;

3. identifying the main industry of local systems, mainly manufacturing of small to medium-sized enterprises;

4. identification of industrial districts.

For each of the local labour markets, territorial concentration ratios were calculated, using the data for employees in local economic units recorded in the IX General Census of Industry and Services (ISTAT, 2011). Next, they used the employment data for local units of enterprises, public institutions and non-profit institutions to compare the proportion of the local system in a particular productive sector with the national share of the same sector.

Following the order of the above-given list, we get the following procedure, comprising four phases:

Step 1: Identification of local systems mainly manufacturing.

For each of the local labour systems on the national territory (SLL) is calculated by a coefficient of territorial concentration in each of its businesses, which make up the productive sectors of industry and services, by making the following report, based on Ateco classification (ISTAT, 2009):

\section{(SLLadd, ateco / ITAadd, ateco) / (SLLadd, tot / ITAadd, tot)}

where

SLLadd, ateco indicates the employees of a single economic activity in a local system;

ITAadd, ateco indicates the employees of a single economic activity in Italy;

SLLadd, tot indicates the total number of employees in the local system;
ITAadd, tot indicates the total employees (industry and services) in Italy.

For local systems that have index values above the national average in manufacturing or in services to companies or consumer services sector, the prevalence is calculated, in order to verify which of the three groupings of economic activity prevails at the level of the local system:

[(SLLadd, ateco / ITAadd, ateco) - (SLLadd, tot / ITAadd, tot $)]^{\star}$ ITAadd, ateco

The highest value (employment base) in one of the economic activities (manufacturing, business services and consumer) indicates the prevalence. When in a local system, this value corresponds to the manufacturing industry, where the local labor market is considered to be mainly manufacturing.

Employment areas, mainly manufacturing, are identified at the end of this step.

Step 2: Identification of local systems mainly manufacturing of small to medium enterprises

For each local system and for each size class of the local unit - or micro (up to 9 employees), small (10 to 49 employees), medium (50 to 249 employees) and large (250 or more employees) - is calculated by the following coefficient of territorial concentration:

(SLLadd (clad), manif / ITAadd (clad), manif) / (SLLadd, manif / ITAadd, manif)

where

SLLadd (clad), manif indicates the employees of each size class production units of manufacturing in a local system;

ITAadd (clad), manif indicates the employees of each size class production units of manufacturing in Italy;

SLLadd, manif indicates the manufacturing industry workers in a local system;

ITAadd, manif indicates the workers in the manufacturing industry in Italy. 
After the procedure, you get the local manufacturing systems of small and medium-sized enterprises (MSME). The local labor systems of large enterprises are treated separately to determine how many of them have "District".

Step 3: Identify the main industry of local systems mainly manufacturing of small to medium-sized enterprises

The local systems mainly for manufacturing MSMEs are now examined in order to identify the main industry that characterizes the local economy.

The first step is to calculate, for each local manifacturing system of MSMEs, a coefficient of territorial concentration relative to each of the types of industry in which manufacturing was distributed. The formula used is as follows:

(SLLadd, ind / ITAadd, ind) / (SLLadd, man / ITAadd, man)

where

SLLadd, ind indicates the employees of a single type of industrial system, mainly local manufacturing;

ITAadd, ind indicates the employees of a single range of industries in Italy;

SLLadd, man indicates the manufacturing industry workers in the predominantly local manufacturing;

ITAadd, man indicates the workers in the manufacturing industry in Italy.

The next step implies comparing the local systems which have a coefficient of spatial concentration in the types of industries greater than the national average to determine the prevailing type. To determine this prevalence, the second formula applies, as follows:

[(SLLadd, ind / ITAadd, ind) - (SLLadd, man / ITAadd, man) $] *$ ITAadd, ind

The highest value (employment base) in one of the types of industries indicates the prevalence and corresponds to the industry's main local system.

\section{Step 4: Identification of industrial districts}

A local system mainly manufacturing of MSMEs is identified as industrial district when its main industry consists mostly of small and medium-sized production units, if they occur in conjunction with the following two conditions:

a) (SLLadd (mpmi), ind_p / SLLadd (tot), ind_p) $>50,0 \%$

where

SLLadd (mpmi), ind_p indicates the main industry workers employed in SMEs in a local system, mainly manufacturing of MSMEs;

SLLadd (tot), ind_p indicates the total employees in the main industry, mainly a local manufacturing of MSMEs.

b) (SLLadd (m_imp), ind_p / SLLadd (m_imp), ind_p) $>50,0 \%$

(SLLadd (p_imp), ind_p/SLLadd (m_imp), ind_p) $>50,0 \%$

where

SLLadd ( $\left.m \_i m p\right)$, ind_p indicates the main industry workers employed in production units of micro size in a predominantly local manufacturing of MSMEs;

SLLadd ( $\left.p \_i m p\right)$ ), ind_p indicates the main industry workers employed in production units of small size in a predominantly local manufacturing of MSMEs;

SLLadd ( $\left.m \_i m p\right)$, ind_p indicates the main industry workers employed in production units of medium size, when there is only one production unit, in a predominantly local manufacturing of MSMEs.

At the end of this procedure, you will get the clusters of MSMEs. For identification of the local labor systems of large companies with district characteristics, given that the first two steps are common to all types of employment areas, it comes to adapting the steps 3 and 4 to enterprises, mainly manufacturing, with a number of employees of 250 and beyond.

For more details, please see the relevant volume recently published by ISTAT. 


\section{RESULTS AND DISCUSSION}

Industrial districts in Tuscany (17) are almost all included in the provinces of Pisa-Lucca-PistoiaPrato-Florence-Arezzo.

Three districts are in the province of Siena.

Two out of seventeen industrial clusters were the characteristic of large enterprises and are located in the area of Barga (LU) and Montevarchi (AR).

There is no area of this district in the provinces of Massa-Carrara, Livorno and Grosseto.

In total, 117 municipalities are included in the industrial districts, of which 21 large enterprises.

The districts have a population of $1,489,303$ inhabitants, i.e., 146,663 units and 551,226 local employees, according to its Census of 2011.

In figures, districts are marked with a black stroke.

Figure $1^{1}$ clearly shows that as many as 12 districts are distributed along the ridge-shaped arc that connects the provinces of Pisa, Lucca, Pistoia, Prato, Florence and Arezzo.

In fact, according to the summary of impedance functions, using the arithmetic mean, these areas are the most attractive/accessible in the region, with three districts of the province of Siena, which are wedged near the Arezzo area.

Also Figures 2 and 3 clearly show the distribution of districts; these cartograms, based on the "population served", show how the industrial districts of Tuscany can be distributed precisely in the areas where infrastructure is more easily accessible.

In fact, the main area of settlement of industrial districts follows the director of the A1 motorway, which crosses it entirely, to connect to the A11 at A12 towards Florence and Pisa.

1 Missing data in the figures refer to the municipality of Florence, which is treated separately, and the towns of Figline e Incisa Valdarno, Scarperia e San Piero, Crespina Lorenzana, Castelfranco Piandiscò, Pratovecchio Stia, Silano Giuncugnano, Casciana Terme Lari e Fabbriche di Vergemoli, which were established during the period 2014-2015.
As regards the type of districts, Table 1 provides an overview of main activities, which are the typical centuries-old tradition of the region. Mainly, those include textiles - clothing, leather processing and leather for making of shoes and bags, jewelry and paper and paperboard processing.

Prato district is particularly interesting, which started from artisan businesses in the textile - apparel and has built a solid reality in the industrial sector, as highlighted by other authors (Dei Ottati, 2015).

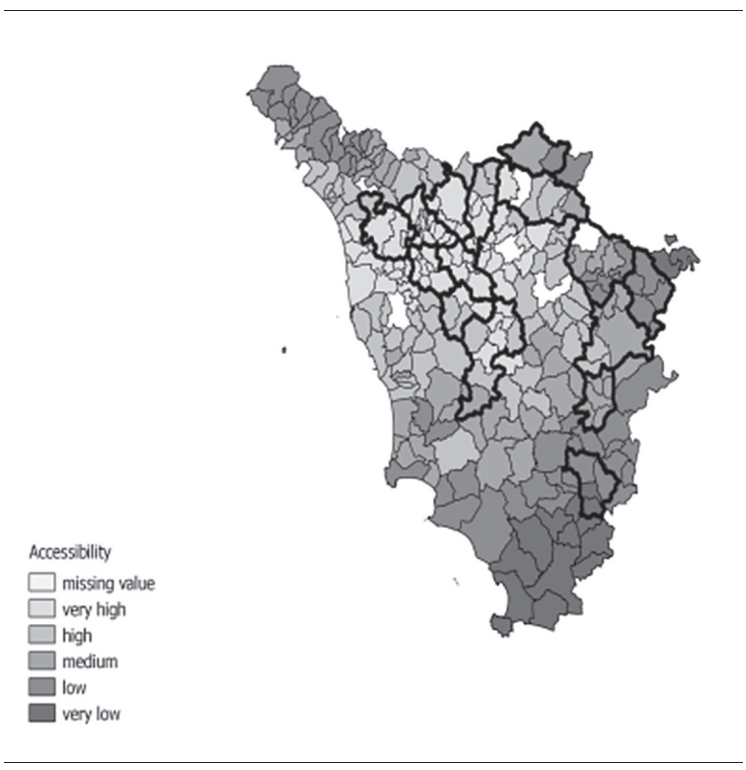

Figure 1. Based on "simple average"

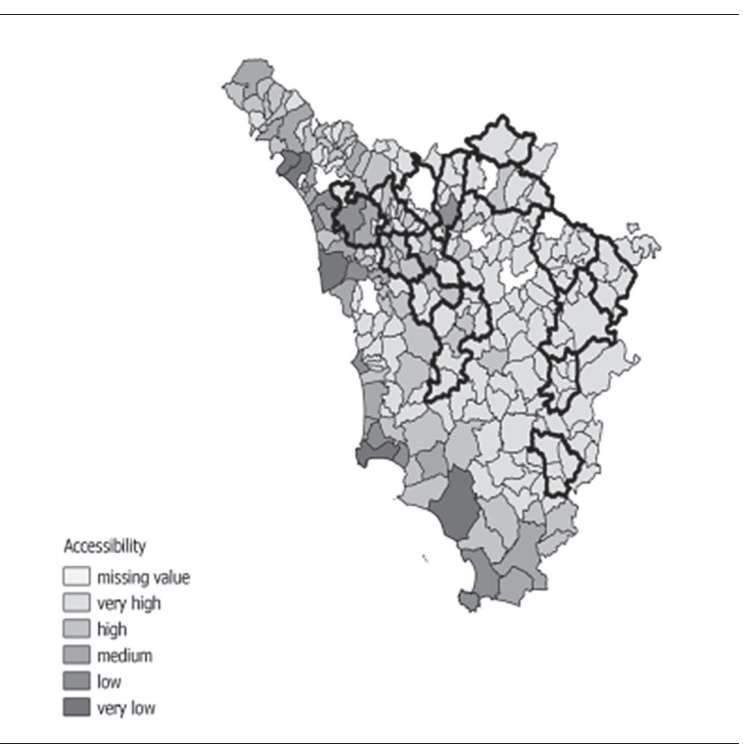

Figure 2. Based on WA 


\section{THE CASE STUDY OF FLORENCE}

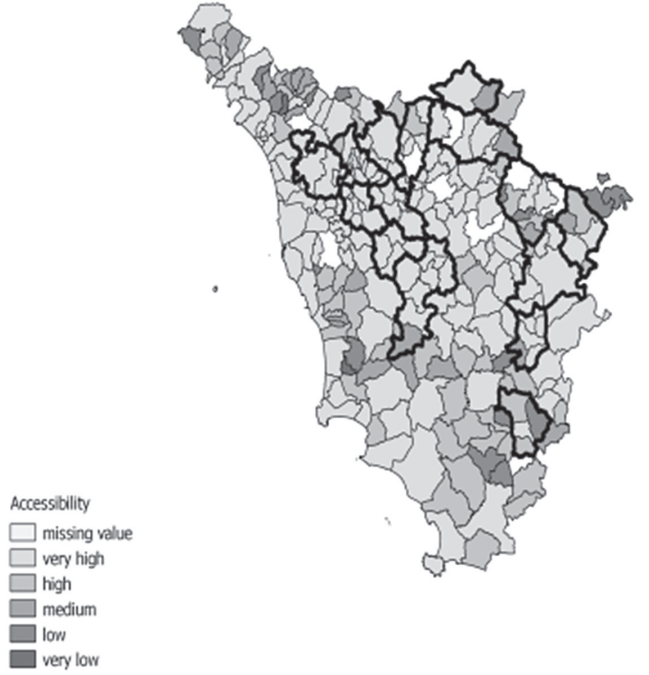

Figure 3. Based on AWI

Table 1. Distribution of industrial districts of Tuscany 2011

\begin{tabular}{|c|c|}
\hline Industrial Districts & Specialization \\
\hline LUCCA & $\begin{array}{l}\text { Papermaking industries and } \\
\text { polygraphic industry }\end{array}$ \\
\hline $\begin{array}{l}\text { MONTECATINI - } \\
\text { TERME }\end{array}$ & Skins, leather and footwear \\
\hline PISTOIA & Textiles and clothing \\
\hline BORGO SAN LORENZO & Skins, leather and footwear \\
\hline CASTELFIORENTINO & Skins, leather and footwear \\
\hline EMPOLI & Textiles and clothing \\
\hline FIRENZUOLA & Mechanic industry \\
\hline SAN MINIATO & Skins, leather and footwear \\
\hline AREZZO & $\begin{array}{l}\text { Jewelry, musical instruments } \\
\text { etc. }\end{array}$ \\
\hline BIBBIENA & Household goods \\
\hline SANSEPOLCRO & Textiles and clothing \\
\hline PIANCASTAGNAIO & Skins, leather and footwear \\
\hline POGGIBONSI & Household goods \\
\hline SINALUNGA & Household goods \\
\hline PRATO & Textiles and clothing \\
\hline $\begin{array}{l}\text { BARGA } \\
\text { (large company) }\end{array}$ & $\begin{array}{l}\text { Papermaking industries and } \\
\text { polygraphic industry }\end{array}$ \\
\hline $\begin{array}{l}\text { MONTEVARCHI } \\
\text { (large company) }\end{array}$ & Skins, leather and footwear \\
\hline
\end{tabular}

Source: based on ISTAT data
The main city of the region was deliberately isolated from the map, to be analyzed separately.

As for accessibility, extensive dissertation on this subject was conducted by the author in earlier studies (de Candia et al., 2014; de Candia, 2015) analyzing the location of the infrastructure present for each constituency/district ${ }^{2}$.

The capital also lies outside the district areas, as part of a non-manufacturing local system, of less interest for the current analysis.

Florence deserves to be further researched, as regards the urban strategies of development of the transportation plan TOD (Transit-Oriented Development) highlighted by other authors (Papa et al., 2015).

Considering the importance of the town and the central role in the administrative region, the further increase of analysis and research could address the role of the capital in an attempt to increase investments in R \& D by companies, encourage the process of internationalization, as well as investments associated with the supply chain (Colovic, 2007).

Another aspect to be carefully analyzed is the possibility of building a model of multi-modal transportation network (Djurhuus, 2015), which would facilitate commuting - work of the people not only of the capital, but the entire region.

\section{CONCLUSIONS}

The map clearly shows the accessibility/territorial attractiveness traced using the logistic function as impedance fits perfectly with the distribution of industrial districts.

This not only demonstrates the effectiveness of the model used and delivers more than gratifying results, but it also shows that the distribution of districts slavishly follows those territories, municipalities, which are most supplied with the basic infrastructure, as well as the improved accessibility.

2 The town of Florence is divided into 5 districts/neighborhoods: Centro storico, Campo di Marte, Gavinana-Galluzzo, Isolotto-Legnaia e Rifredi. 
Therefore, the company chooses to locate where the territory has the best features to facilitate trade in goods and services, as described in detail in the case of Tuscany.

In addition, the company itself tends to change the territory onto which it settles, depending on the operation mode it has within the same territory.

In the case of Tuscany, farms and related districts have found fertile ground, as the region is suitable for the establishment of manufacturing enterprises, able to "create a system". In fact, most of the Tuscan industrial districts activities have been present for centuries on the territory.

A further boost to this type of study lies in the possibility to expand to all Italian municipalities. Furthermore, in order to provide a detailed map of the territorial accessibility and their possibility of establishment at the municipal level, this type of research may involve not only Italy but the entire Europe.

Especially, in the light of the recent and terrible killings involving the city of Paris and other European cities, it seems necessary to be better conversant with the territory and involve all local stakeholders, in order to successfully manage and prevent all criminal acts.

Tuscany is a good example of how to create the paths of business development together with the local governance in order to improve the socio-economic performances of the region (Porter, 2003).

Further research may relate to the assessment of the concept of proximity and location of activities of the population (Torre et al., 2005) in the light of the distribution of industrial districts and, more generally, production activities.

\section{REFERENCES}

Becattini, G. (2000). Il distretto industriale. Un nuovo modo di interpretare il cambiamento economico. Torino: Rosenberg \& Sellier. In Italian.

Colovic, A. (2007). Appropriability, Proximity, Routines and Innovation. In: DRUID Summer Conference, 2007-06-18, Copenhagen.

de Candia, G. (2015). Accessibility to Nodes of Interest: Demographic Weighting the Logistic Model. Expert Journal of Economics, 3(3), 155-160. de Candia, G., \& Chiocchini, R. (2014). Accessibility to nodes of interest: A practical application of the various forms of the impedance curves. Romanian Review Of Regional Studies, 10(1), 47-56.

Djurhuus, S., Hansen, H. S., Aadahl, M., \& Glümer, C. (2015). Building a multimodal network and determining individual accessibility by public transportation. Environment and Planning B, 43(1), 210-227. doi:10.1177/0265813515602594.

ISTAT. (2009). Classificazione delle attività economiche Ateco 2007, Istat, Metodi e norme n. 40 Anno 2009. Retrieved March 30, 2016, from http://www3.istat. it/dati/catalogo/20090615_00/. In Italian.

ISTAT. (2011). $15^{\circ}$ Censimento generale della popolazione e delle abitazioni. Retrieved March 30, 2016, from http://www.istat.it/it/files/2012/12/volume_ popolazione-legale_XV_censimento_popolazione. pdf. In Italian.

ISTAT. (2011). $9^{\circ}$ Censimento dell'industria e dei servizi e Censimento delle istituzioni non profit. Retrieved March 30, 2016, from http://www.istat.it/it/censimento-industria-e-servizi/industria-e-servizi-2011. In Italian.

ISTAT. (2014). I sistemi locali del lavoro 2011, Nota metodologica. Retrieved March 30, 2016, from http:// www.istat.it/it/archivio/142676. In Italian.

ISTAT. (2015). I distretti industriali 2011. Retrieved March 30, 2016, from http://www.istat.it/it/files/2015/10/Idistretti-industriali-2011.pdf. In Italian.

Marshall, A. (1890). Principles of economics. London: Macmillan.

Ottati, D.G. (2015). Global competition and entrepreneurial behaviour in industrial districts: Trust relations in an italian industrial district. Retrieved March 30, 2016, from https://www.researchgate.net/ publication/241202242_Global_competition_and_ entrepreneurial_behaviour_in_industrial_districts_ Trust_relations_in_an_Italian_industrial_district

Papa, E., \& Bertolini, L. (2015). Accessibility and Transit-Oriented Development in European metropolitan areas. Journal of Transport Geography, 47, 70-83. doi:10.1016/j.jtrangeo.2015.07.003

Porter, M. (2003). The Economic Performance of Regions. Regional Studies, 37(6/7), 549-578. doi:10.1080/0034340032000108688

Torre, A., \& Rallet, A. (2005). Proximity and Localization. Regional Studies, 39(1), 47-59. doi:10.1080/0034340052000320842 


\section{PRISTUP ČVORNIM TAČKAMA: DISLOKACIJA INDUSTRIJSKIH OBLASTI U TOSKANI}

\section{Rezime:}

U radu je dat prikaz različitih iskustava autora na temu atraktivnosti/dostupnosti teritorija. Za potrebe analize korišćen je gravitacioni model. Tačnije, logistika je korišćena kao funkcija impedanse, koja je do sada pružila najbolje rezultate prilikom sprovođenja analize teritorija. Celokupan postupak se sprovodi na opštinskom nivou. Rad ima za cilj da ispita vezu između ovih radova i mape indusrijskih oblasti koju je nedavno objavio Nacionalni institut za statistiku (ISTAT). Kao i u drugim publikacijama, analizom je obuhvaćena italijanska regija Toskana, koja daje detaljne podatke o dostupnosti na opštinskom nivou u odnosu na lokaciju industrijskih klastera. Grad Firenca je zasebno posmatran. Cilj rada jeste da se tvorcima politike pruže najbolje i najpreciznije informacije za potrebe upravljanja teritorijama u ekonomskom i finansijskom smislu.

\section{Ključne reči:}

regionalni razvoj, kriva impedanse, teritorijalni statistički podaci, infrastruktura, industrijske oblasti, opština. 